Praca podzielona jest na dwie zasadnicze części. Pierwsza omawia teologiczny sens błogosławieństw, ich znaczenie we wspólnocie wierzących, walor słowa Bożego zawierającego się w obrzędzie błogosławieństw. Nie pominięto także sprawy, kto może błogosławić, jak i konkretnej praxis (śpiew, muzyka). Podkreślić także należy omówienie znaczenia błogosławieństw $u$ protestantów oraz w liturgii ekumenicznej. Druga natomiast część pracy podejmuje omówienie ważniejszych błogosławieństw w roku liturgicznym (153-258), w różnych okolicznościach życia ludzkiego (259-334) i szczególnych okazjach (334- 387-6). Praca opatrzona jest wykazem autorów i rzeczowym indeksem, co znacznie ułatwia odszukanie interesującej sprawy.

Wartość omawianej pracy mierzy się najpierw kompetencją autorów. Niemniej jednak w założeniu, że komentarz posiada charakter duszpasterski powoduje ona często swoistą ucieczkę objaśnień w dane historycz-ne. Nie czuć w nich serca i ,ręki” duszpasterza. Jeszcze w większym zakresie wartość pracy mierzy się zapotrzebowaniem wiernych na błogosławieństwa. Mówić trzeba w liturgii o pewnym nawrocie do elementów ,swoistych", bliskich. Stanowi to przeciwwagę zbytniego intelektualizowania - przynajmniej w religijności Niemców.

Praca stanowi cenną pomoc dla liturgistów, a przede wszystkim: katechetów i duszpasterzy.

Poznań

KS. BOGUSŁAW NADOLSKI TChr

ABP DAMIAN ZIMOŃ, Czas zbawienia (Rok liturgiczny $A, B, C$ ), t. I-II, Księgarnia św. Jacka, Katowice 1992 r.

W wydawnictwie Księgarni św. Jacka w Katowicach ukazał się bardzo starannie wydany, 3-tomowy zbiór rozważań, Metropolity Katowickiego, abpa Damiana Zimonia Czas zbawienia. Rozważania przeznaczone na każdą niedzielę roku liturgicznego nie są zbiorem homilii, lecz komentarzy do sprawowanej liturgii.

We wstępie czytamy: „Komentarze liturgiczne dotyczą tego wszystkiego co jest Słowem Bożym w liturgii, ale przede wszystkim obrzędu. Obrzęd liturgiczny też wymaga komentarza (...). Komentarze zgrupowane są wokół roku kościelnego, którego szczytem i ośrodkiem są święte dni Triduum Paschalnego. Rok liturgiczny to tajemnica Chrystusa wpisana w czas, aby człowiek zawsze mógł się spotkać z rzeczywistością zbawienia" (s. 3). Ta myśl stale towarzyszy Autorowi rozważań, stąd tytuł Czas zbawienia. Jednocześnie jako duszpasterz, jest świadom, iż liturgia sama nie jest $w$ stanie wyrazić swoich twórczych możliwości i przedstawić swoich uświęcających mocy. Jest uwarunkowana przygotowaniem do owocnego w niej uczestnictwa (wiara, znajomość znaków, symboli) i wymaga kontynuacji poprzez pogłębienie treści przyjętego daru (katecheza mystagogiczna). Tylko w ten sposób liturgia staje się „didascalia ecclesiae” (Pius XI).

Rozważania Czas zbawienia są próbą swoistej mystagogii, refleksji która wyjaśnia obrzęd i przybliża tajemnicę sprawowanych w ciągu calego roku liturgicznego „Mysteria Christi”. Pod tym względem pozycja jest jedną $\mathrm{z}$ nielicznych publikacji podejmującej się takiego przedstawienia celebracji roku liturgicznego.

We wstępie zbioru, czytamy: „Liturgia jest przedziwną symbiozą nova et vetera, tego co dawne i tego, co nowe" (s. 6). Często więc w komentarzach znajdujemy nawiązanie do różnych tradycji i zwyczajów związanych z rokiem liturgicznym. Autor stara się ukazać nie tylko ich historię, ale i wskazać na sposoby ich adaptacji do warunków i men- 
talności współczesnego czlowieka tak, aby przeżywanie roku liturgicznego i udział wiernych w liturgii Kościoła był świadomy, czynny i owocny (por. KL, 21). Jan Paweł II, w liście apostolskim z okazji XXV lecia ogłoszenia Konstytucji o Liturgii przypomina, by pobożności ludowej nie lekceważyć ani traktować z obojętnością czy pogardą. „Jednak pobożność ta stale potrzebuje ewangelizacji, aby wiara, którą wyraża, stawał się wciąż bardziej dojrzała i autentyczna" (n. 18).

Rozważania są owocem nie tylko studiów liturgicznych Autora, ale i doświadezenia duszpasterskiego. Stąd też zbiór rozważań skierowany jest do wszystkich, którzy jako Lud Boży gromadzą się w kościołach, by sprawować Pamiątkę Pana. W sposób szczególny pomocny będzie duszpasterzom, którzy mają przybliżać wiernym "Mysteria Christi" celebrowane w ciągu roku liturgicznego i podjąć dzieło nowej ewangelizacji.

Katowice - Rzym

KS. ROMAN KEMPNY

KS. HENRYK PIETRAS, SJ, Dzień święty. Antologia tekstów patrystycznych o świętowaniu niedzieli, Wyd. Apostolstwa Modlitwy, Kraków 1992, ss. $144+$ nlb.

Ks. Henryk Pietras SJ, wykładający patrologię w Kolegium Księży Jezuitów $w$ Krakowie i na Gregorianum w Rzymie, opracowal antologię tekstów sięgających do VII wieku, a dotyczących świętowania niedzieli w starożytnym Kościele. Oparł się na kartotece, jaką odziedziczył po miłośniku i znawcy antyku chrześcijańskiego, ks. Andrzeju Boberze SJ. Prace otwiera obszerne wprowadzenie ks. Pietrasa na temat biblijnych świadectw świętowania niedzieli i głównych przyczyn tegoż świętowania. Teksty patrystyczne zostały rozłożone $\mathrm{w}$ sześciu rozdziałach problemowych: I. "Fałszywy trop" o niewłaściwych (heterodoksyjnych) interpretacjach niedzieli; II. „Dzień pierwszy i ósmy” o duchowej interpretacji liczbowej; III. „Dzień przewyższający szabat” o wyzwoleniu z legalizmu starotestamentalnego, IV. „Dzień święty” o świętości niedzieli; V. „Liturgia niedzieli" o sprawowaniu Eucharystii; VI. "Zwyczaje i normy prawne”, czyli prawodawstwo niedzieli. Autor zwraca uwage na przesuwanie sie akcentów świętowania niedzieli: ,(...) dla pierwszych chrześcijan było nie do pomyślenia, by w niedzielę nie uczestniczyć we Mszy świętej i nie przystąpić do komunii, nie zwracano natomiast uwagi na pracę $w$ ten dzień. Później odpoczywano $\mathrm{w}$ niedziele, natomiast komunia zaczęła być czymś coraz bardziej wyjątkowym". (s. 142). Książka pożyteczna dla praktyki duszpasterskiej przywracania właściwej rangi niedzieli.

Kraków

KS. JERZY CHMIEL

\section{A. I. STARCZEWSKA, Listy do Ciebie, Warszawa 1990}

Jan Paweł II $\mathrm{w}$ czasie swego ostatniego pobytu $\mathrm{w}$ ojczyźnie zajął się w swych homiliach wyjaśnianiem zasad Dekalogu. W związku z tym pisal publicysta „Przeglądu Tygodniowego" (10 06 1991): „Oczekiwany jako jedyny autorytet, po którym spodziewano sie rozstrzygnięć sporów targających spoleczeństwo, papież przybył $z$ misją rozpoczęcia swym nauczaniem nowej ewangelizacji Polski... W homiliach interpretowal przykazania Dekalogu. Mogło to budzić pewne zawstydzenie, że naród, szczycący się ponad tysiącletnią tradycją chrześcijaństwa, musi zostać poddany ponownej ewangelizacji, że zaledwie 40 lat komunizmu stanowi wy- 